\title{
OKSANA VAKHROMEEVA
}

Saint Petersburg State University of Industrial Technologies and Design

iD

ORCID: http://orcid.org/0000-0001-9936-3159

\section{«Глубоко-гуманное вдияние педагога Виктора Острогорского» Образ Шейлока Ивана Гревса по Венециианскому купиу Уильяма Шекспира}

"Wpływ humanisty-pedagoga Wiktora Ostrogorskiego".

Obraz Shylocka u Iwana Griewsa na podstawie Kupca weneckiego Williama Szekspira

Streszczenie: Artykuł omawia jedyny żydowski wątek, którym zajmuje się w swojej działalności naukowej petersbursko-leningradzki mediewista, profesor Iwan Michajłowicz Griews (1860-1941). Autorka jako pierwsza podejmuje próbę wyjaśnienia początków i dalszego zainteresowania Griewsa, będącego na przełomie lat 70. i 80. XIX stulecia bardzo młodym człowiekiem, twórczością wielkiego angielskiego dramatopisarza Williama Szekspira, w kontekście wzajemnego zrozumienia przedstawicieli dwóch różnych kultur - Wenecjan i Żydów.

Słowa kluczowe: Ostrogorski, Gedda, Czernyszewski, Griews, edukacja literacka, Shylock, Szekspir

"Deeply humane influence of the teacher Viktor Ostrogorsky".

Ivan Greavs' image of Shylock based on The Merchant of Venice by William Shakespeare

Abstract: The article is devoted to the only Jewish plot, which can be traced in the work of Professor Ivan Mikhailovich Greavs (1860-1941). For the first time in historiography, an attempt has been made to highlight the emergence and development of a steady interest in Greavs' interest in the work of the great English playwright William Shakespeare, and through it to the topic of mutual understanding of representatives of two different cultures, Venetians and Jews.

Keywords: Ostrogorskiy, Gedda, Chernyshevskiy, Greavs, literary education, Shylock, Shakespeare

В персональном фонде петербургского-ленинградского медиевиста Ивана Михайловича Гревса (1860-1941), хранящемся в Санкт-Петербургском филиале Архива Российской Академии наук (СПбФ АРАН. Ф. 726) сосредоточено немало материалов, раскрывающих отношение историка к различным религиозным верованиям и культурному мировоззрению народов, но еврейской тематике посвящена лишь одна работа. Будучи 19-летним юношей, в 1879-1880 гг. Гревс написал историческую новеллу 
Венецианский купец (по Шекспиру), в которой подверг анализу лучшую, по его мнению, пьесу английского драматурга.

Много лет спустя, размышляя над понятиями «история» и «культура», ученый пришел к выводу, что «история есть е д и н с т в о, которое делает для нас близким и необходимым - ее древность, как ее современность»; «великим и одухотворяюще цельным» двигателем истории выступает культура, которая «есть следствие познания творчества»'.

Гимназист VII класса Иван Гревс, раскрывший образ еврейского купца Шейлока, еще не помышлял о «духе человека» как основе «единства исторической культуры», но в своем переводе он указал на то, что хозяйственная сущность и общественная деятельность евреев в Венеции относились только ко второму свойству. Вместе с тем, душа еврейского народа была показана им через объединение и содружество людей одной веры, их образ жизни, вызывавшие отторжение у представителей иных культур.

Пьеса Венецианский купец Уильяма Шекспира, впервые изданная в Лондоне в 1600 г., представала собой мастерски сведенный воедино клубок мотивов (история с векселем - из сборника новелл Джованни Фиорентино Простак 1558 г.; женихи, гадающие на шкатулке - 66-й рассказ средневекового сборника Римские деяния около 1440 г.; антиеврейская тема после казни в 1594 г. оклеветанного личного медика королевы Елизаветы еврея Лопеса). В главной части фабулы это комедия, но с грустными и печальными нотами. Веселье венецианского светского общества, как и мрачные мотивы пьесы - две стихии, романтическая и реалистическая, предложенные Шекспиром на суд читателя начала XVII в.

Центральным конфликтом пьесы Шекспир полагал: кто прав - венецианцы или Шейлок. Кроме того, автор задавался вопросами: как оценить с нравственной точки зрения желание Шейлока вырезать у должника Антонио фунт мяса; может ли читатель сочувствовать представителю угнетаемого народа; наконец, кто страдает больше, христианин Антонио или еврей Шейлок?

По ходу пьесы Шекспир наводит читателя на мысль, что Шейлок ненавидит венецианского купца Антонио (представителя нового буржуазного класса) не за то, что тот христианин, а за то, что он мешает его коммерческим делам (давая в долг, не берет проценты и сбивает ростовщический курс). Вывод 
о том, что Шекспир вместе с венецианцами осуждает Шейлока за ростовщичество, а не как еврея, подробно изложен в трудах шекспироведов: Александра Аникста Творчество Шекспира $^{2}$ и Александра Смирнова Уильям Шекспир. Избранные произведения ${ }^{3}$.

Шекспир показывает венецианцев далеко не идеальными людьми (легковерными, праздными), но их главной добродетелью он считает человечность. Шейлок же выступает на стороне зла и, следовательно, нечеловечности. Таким образом, английский драматург указал на существовавшую проблему в обществе - «жиды как враги христиан», призывая обратиться к моральной оценке поступков людей, вне зависимости от их веры. Гревс-переводчик в свою очередь полагал правильным выяснить причины антиеврейского настроения в венецианском обществе. Именно поэтому, помимо перевода пьесы, он изложил историю еврейского народа, чем внес определенный вклад в анализ пьесы Шекспира Венецианский купец.

Драматические конфликты в пьесе иногда перевешивают жизнерадостность венецианцев (хорошо прописанную Шекспиром в герое Бассанио и его беззаботных приятелях), например, когда Шейлок в суде, находясь на стороне формального права и не желая видеть сущность происходящего, с ножом в руке требовал неустойку. Такому герою нет пощады, и венецианцы в лице Порции (главного положительного персонажа комедии, молодой женщины, переодевшейся адвокатом и произнесшей в суде знаменитую речь) обратили формальное право против «жида». В результате ростовщик потерял капитал (самое ценное свое сокровище, гарантировавшее ему защиту от ненавидящих его христиан) и поддержку со стороны евреев-венецианцев (суд приговорил его принять христианство, после чего он избрал путь «вечного одинокого странника»).

Шекспир разрешил конфликт в духе торжества светлых начал жизни. Пьеса относится к периоду его творчества, характеризовавшемуся избытком жизнерадостности, когда драматург верил, что комизм (от тонкого юмора до грубоватых острот), выражавшийся яркими и забавными шутками, поможет преодолеть драматическое начало. В целом, противоречия, затронутые в шекспировской пьесе, заставляли и застав-

\footnotetext{
А. Аникст, Творчество Шекспира, Издательство художественной литературы, Москва 1963, с. 615.

А. Смирнов, Уильям Шекспир. Избранные произведения, Государственное издательство «Художественная литература», Ленинград 1939, с. 386.
} 
ляют новые поколения внимательных читателей искать новое решение конфликта.

Юный Гревс обожал Шекспира, был хорошо знаком с его творчеством и, как многие молодые люди 1870-1880-х гг., гимназисты и студенты, был увлечен театром. Обращаясь к трактовке ключевой проблемы шекспировской пьесы - конфликту между христианином и иудеем, Гревс выступал не только как представитель гимназического литературного кружка, в его переводе прозвучали первые, пока робкие, интонации ученого-историка. Он изложил историю Венецианской республики, дал характеристику евреям как людям, не имеющим родины, но обладавшим даром накопления материальных богатств. Последний обернулся проклятием для Шейлока: страсть к накопительству лишила его общества единственной дочери, поддержки со стороны единоверцев и в конечном итоге - родного дома.

Главным вдохновителем ученика был его педагог по литературе - Виктор Петрович Острогорский (1840-1902), незаурядная личность и учитель-новатор, предложивший новый метод литературного воспитания гимназистов. Спустя десять лет после его кончины, 31 марта 1912 г., по инициативе Правления «Общества попечения о Валдайской бесплатной школе В.П. Острогорского» в С.-Петербургской частной женской гимназии Елизаветы Михайловны Гедда (ул. Глинки, дом № 6) в три часа дня состоялось самое представительное собрание памяти «педагога-романтика второй половины XIX столетия». В числе собравшихся был и Гревс ${ }^{4}$.

Устроительница памятной встречи - Елизавета Михайловна (старшая дочь сенатора Михаила Гедда и Елизаветы Шредер) была выпускницей Коломенской женской гимназии и Педагогических женских курсов, исключительного учебного заведения, сочетавшего общеобразовательную и педагогическую подготовку курсисток (1875 г.), на которых Острогорский преподавал литературу. В 1881 г. Гедда приобрела у г-жи Лосевой перворазрядную школу для девочек, из которой создала частную женскую гимназию с правами гимназий Министерства народного просвещения (1883 г.), а позже правами правительственных гимназий. По наблюдению историка естествознания Бориса Райкова, «Елизавета Михайловна была очень умная, деятельная, энергичная женщина мужского склада». Она возглавляла гимназию 31 год (все задуманное в середине

См. СПбФ АРАН. Ф. 726. ОП. 1. Д. 37 (Памяти В. П. Острогорского). Л. 106.

Б.Е. Райков, На жизненном пути: автобиографические очерки, Коло, Санкт-Петербург, 2011, с. 441. 
1870-х гг. ею было осуществлено в стенах частного женского учебного заведения - «человечность, взаимопонимание и сотрудничество» ${ }^{6}$.

Гедда поддержала предложение валдайцев почтить память Острогорского - прекрасного, доброго человека и удивительного, творческого педагога, которому была многим обязана. Она много лет с большим успехом применяла на практике разработанную Виктором Петровичем методику организации эмоционально-образного восприятия литературы. Как и Острогорский, Гедда рассматривала образование и воспитание в виде единого процесса. Она была в числе тех почитателей глубокого педагогического таланта Виктора Петровича, кто принял на веру специально разработанный им курс гимназического литературного образования, понимая литературу, как основу этико-эстетического воспитания молодого поколения?.

Острогорский получил образование в III Петербургской гимназии и на историко-филологическом факультете С.-Петербургского университета (1862 г.). Со студенческих времен он был захвачен «большой педагогической работой», полагая, что любой предмет, а тем более такой важный, как образование, должен иметь «понятную форму». Острогорский посвятил свою жизнь преподаванию словесности, истории русской и всеобщей литературы в различных учебных заведениях столицы (наиболее плодотворным периодом был «ларинский» с 1871 по 1892 г., когда он служил учителем русского языка и словесности в IV Ларинской гимназии). Об этом периоде подробно написал в 1902 г. его ученик (1872-1879 гг.), профессор Гревс ${ }^{8}$.

Гревс был глубоко привязан к Острогорскому. Он писал:

Для большинства же гимназистов-«ларинцев», пребывавших в стенах этого учебного заведения в 70-х гг. XIXв., он был центром духовной жизни. Светом, исходившим от его симпатичной личности, красилась и согревалась мрачная и холодная атмосфера тяжелой учебной действительности, окружавшей обыкновенно детей в рассадниках классического просвещения того времени. Слушая В. П., общаясь с ним, вспоминая его, ученики действительно привыкали соединять с понятиями «школа», «учитель» признак чего-то уважаемого и дорогого, такого, что притягивает к жизни

6 К.В. Романенчук, К.С. Туманина, Педагогическая деятельность Е. М. Гедда // Воспитание и социализация молодежи: потенциал историко-педагогического познания в контексте вызова современности, Ред.-изд. центр ВГАПО, Волгоград, 2018, с. 333.

7 См. СПбФ АРАН. Ф. 726. 0П. 1. Д. 37. Л. 3-306.

8 См. И.М. Гревс, Виктор Петрович Острогорский, как учитель: (Набросок воспоминаний ученика), Редакция журнала «Мир Божий» 1902, (анкт-Петербург, с. 16. 
в юности, оставляет заветы зрелому возрасту, дает цельность существованию до старости 9

\section{Идею органического единства выразительного чтения} и анализа литературного сочинения Острогорский развил чуть позже, в 1885 г. вышла его книга Выразительное чтение. Гревс замечал:

В. П. задавался целью не только указать, что читать, но и научить, как это делать. Мы рано привыкли, под его влиянием, к самостоятельной работе «читать с пером в руке», отмечая в особые тетрадки и новые мысли, которые привлекали внимание, и понравившиеся отрывки, и вызванные недоумения. Он советовал заводить для такого «домашнего чтения» толстую тетрадь на целый год, в которой заносился бы непринужденно весь накопляющийся материал выписок, конспектов, вопросов, впечатлений, планов, заглавий найденных или указанных книг и т. д. Он говорил, что так будут сохраняться результаты личных занятий, закрепляться картина ежегодной истории души, которую потом приятно и важно будет пересматривать и передумывать ${ }^{10}$.

Специально увязанное в единое целое гимназическое литературное образование дополнялось Острогорским внеклассным чтением, посещением вечеров «Литературного фонда», где свои сочинения представляли Иван Тургенев, Лев Толстой, Федор Достоевский ${ }^{11}$.Гревс писал:

Его мысль направляла домашние занятия отдельных учеников и приводила к сближению между ними. Так, среди моих товарищей уже в V классе возник, под впечатлением преподавания В. П., дружеский кружок, в котором мы занимались вместе литературными, историческими, нравственными, философскими вопросами. Он продержался до самого окончания нами курса гимназии, оказав важное влияние на образование умственного склада его членов, перешел с нами в университет и растаял там только в силу многого различия новых веяний, когда уже выполнил свою функцию. Правда, жизнь этого кружка питалась самостоятельной работой главных участников, но внимание к нему и помощь В. П. не ослабевали до конца ${ }^{12}$.

Историю «Литературного кружка» 1876-1881 гг. по просьбе Гревса написал другой «ларинец», Михаил Чернышевский (1858-1924), который после окончания историко-филологического факультета С.-Петербургского университета (1884 г.) до 1919 г. служил по тарифной части железнодорожного

9 0.Б. Вахромеева, Человек соткрытым сердием. Автобиографическое и эпистолярное наследие Ивана Михайловича Гревса (1860-1941), нИХИ СПбГУ, Санкт-Петербург 2004, с. 89.

10 Там же, с. 91.

11 См. там же, с. 94.

12 Там же, с. 95. 
ведомства, одновременно собирал и хранил материалы, имевшие отношение к его отцу; он стал первым директором Музея-усадьбы Николая Чернышевского в Саратове ${ }^{13}$. Чернышевский-сын отличался хорошей памятью и талантом систематизатора. Он вспоминал: «Действия кружка открылись 17 января 1876 г. - в этот день был утвержден устав и произведены выборы» ${ }^{14}$.

Гревс уклонился от президентства по скромности и стал первым секретарем Литературного кружка. Президентом был выбран Герке, т. к. главным образом собрания проходили у него в доме (в роскошном министерском доме на Морской у Синего моста). Непременные члены: Чернышевский, Цимбиди, Яковлев Владимир. Действительные члены: Селиванов, Яковлев Николай, Россет Феликс и Власов. Кандидаты: Червинский Павел, Петров, Кух. Впоследствии этот маленький итесный кружок пополнился еще несколькими членами (Газенвинкель, Дмитриев, Икорников, Корево, Камп, Лагербек и др.), но до конца сохранил характер тесного интимного кружка молодых людей, с любовью и увлечением интересующихся литературою и искусством. В собраниях принимал участие (в особенности в последние годы) и Виктор Петрович ${ }^{15}$.

Просуществовал кружок ровно пять лет, до 1 марта 1881 г., которое сделало уже почти невозможным существование даже подобных кружков без известного риска ${ }^{16}$.

В 1877 г. Гревс сделал два сообщения: Характеристика Лаэрта и Офелии по Шекспиру и Вступление в философию17. 19 декабря 1878 г. он анализировал первую главу из Истории цивилизаций в Англии Генри Томаса Бокля (труд переведен на русский язык в 1863-1864 гг.).

Интерес к истории Англии и творчеству Шекспира у Гревса поддерживался и тем, что в эти же годы он состоял членом другого объединения - «Кружка литературных вечеров»18, в который входили: братья Федор и Сергей Ольденбурги, князь Дмитрий Шаховской, Александр Корнилов, Лев Оболья-

13 См. Н.М. Чернышевская-Быстрова, Михаил Николаевич Чернышевский: (некролог), «Саратовские известия» 1924, № 99, с. 1.

14 СПбФ АРАН. Ф. 726. 0п. 1. Д. 37. Л. 306.

15 Там же, Л. 5-50б.

16 Там же, Л. 606 .

17 См. там же.

18 См. И.М. Гревс, Личность и дело Ромена Роллана. Опыт истолкования души // 0.Б. Вахромеева (сост., автор предисловия, вступит. ст. и комм. к тексту), Арт-Экспресс, Санкт-Петербург 2017, с. 13-14. 
нинов, Николай Ушинский, Андрей Краснов, Николай Харламов и Владимир Вернадский, называвшие себя впоследствии членами университетского, Приютинского братства. В гимназическую пору молодые люди около одного раза в месяц собирались на квартире братьев Ольденбургов (на 15-ой линии Васильевского острова, в доме № 34, квартире № 4), как самой вместительной, и устраивали литературные встречи. Характер их был самый различный: лекции, декламация, переводы и т. д. Гревс готовился к вечерам систематически и тщательно; занятия литературными переводами он считал значимым явлением в жизни кружка. Осенью 1878 г. он писал подробные Отчеты о занятиях на литературных вечерах, происходивших у Ольденбургов. Известно, что они были устроены по принципу озникновения и развития литературных жанров и стилей; например, два осенних занятия в кружке были посвящены трагедии; чтобы не распыляться, основное внимание было уделено трагедиям Шекспира ${ }^{19}$.

В начале VII класса, 30 сентября 1878 г. в присутствии Острогорского Гревс прочел очерк Памяти умершего Газенвинкеля, один из первых в своей жизни авторских биографических очерков, непревзойденным мастером которых он стал впоследствии. Гревс посвятил его трагически погибшему во время летних каникул в селе Кириллово Псковской губернии другу по гимназии Александру Газенвинкелю (1860-1878), с которым учился три года (1875-1878) ${ }^{20}$.

Весной 1879 г. по случаю окончания гимназии «ларинцы» устроили торжественный ужин, в котором принял участие и Острогорский. Чернышевский вспоминал:

На ужине с большим подъемом чувств было произнесено много речей, из которых в особенности выделялись две: одна - нынешнего профессора Гревса, а другая умершего вскоре от злейшей чахотки Икорникова. Оба они отмечали глубоко гуманное отношение Виктора Петровича к своим ученикам и считали себя и своих товарищей всецело обязанными ему за свое развитие ${ }^{21}$.

После выпускных экзаменов, по указанию Острогорского, Гревс работал над переводом пьесы Венецианский купец Шекспира, остановился на анализе пересказа комедии Карла Густава Ниритца 1873 г. $^{22}$ и критике. Учитель и ученик пере-

19 См. СПбФ АРАН. Ф. 726. ОП. 1. Д. 232 (По участию в кружке литературных вечеров). Л. 9.

20 См. там же. Д. 24 (Несколько слов на память. А.К. Газенвинкель). Л. 1-10б.

21 Там же. Д. 37. Л. 8-806.

22 См. Г. Ниритц, Венецианский купец. Сочинение Шекспира. Для чтения в школе и дома, пер. с нем., Изд. Т-ва М.0. Вольф, Санкт-Петербург 1873, с. 1. 
писывались на протяжении летних месяцев 1879 г. По мере готовности Гревс направлял Острогорскому части рукописи, а тот правил их. Поступив осенью 1879 г. на историко-филологический факультет С.-Петербургского университета, Гревс заканчивал работу над рукописью. Острогорский предложил Гревсу опубликовать его первый труд в «Детском чтении» ${ }^{23}$, превосходно иллюстрированном периодическом издании для детей, где Острогорский состоял редактором. Черновик рукописи сохранился в личном фонде Гревса в СПбФ АРАН ${ }^{24}$.

Первая печатная работа Гревса (Венецианский купец (по Шекcnupy)) вышла в начале 1880 г. ${ }^{25}$ Издание предопределило вид публикации - историческая новелла (малый авторский жанр эпического рода, позволивший сочетать короткий рассказ с преданиями и иными фольклорными формами).

В переводном произведении шесть частей, не соотносящихся с классическими канонами композиции пятиактной пьесы (вступление, завязка, кульминация, развязка и заключение). В первой части Бассанио одалживает деньги у ростовщика еврея Шейлока под поручительство христианского купца Антонио, во второй - Гревс раскрывает мотив вражды христиан и евреев, излагая историю еврейского народа, в третьей автор вкратце описывает историю Венеции и объясняет, как в одном из богатейших городов мира сошлись в конфликте представители двух враждующих религий, в четвертой части речь идет о сватовстве Бассанио к Порции в замке Бельмонта, в пятой - о суде между Антонио и Шейлоком, в шестой части описана идиллическая сцена счастья главных героев.

Композиция пьесы была нарушена Гревсом не с целью вмешательства в драматургию Шекспира, а для адаптации перевода для русскоязычных детей. Художественный перевод представлял собой самостоятельное произведение, но вместе с текстом оригинала продолжал сохранять единство целого. Гревс сумел добиться коммуникативной равноценности между текстами. Для лучшего восприятия читательской аудиторией младшего и среднего школьного возраста пьеса английского драматурга была переведена с учетом эстетической ценности издания «Детское чтение». Но ни выявление лексического соответствия, ни определение грамматических

23 См. 0.Б. Вахромеева, Человек соткрытым сердием..., с. 86-87.

24 См. СПбФ АРАН. Ф. 726. Оп. 1. Д. 19 (Венецианский купец. Популярное литературное изложение по Шекспиру), 29 л.

25 См. И. М. Гревс, Венецианский купец (по Шекспиру), «Детское чтение», (ред. В.П. Острогорский) 1880, т. XXV, с. 1-39. 
возможностей языка перевода или подбор лингвистических средств в языке перевода не могли сравниться для переводчика с целью изучения пьесы как историко-литературного источника. Вместе с тем Гревс высоко ставил художественные приемы Шекспира, например, сцену выбора женихами Порции шкатулок; поэтому ее перевод был выполнен особо тщательно.

Гревс создает образ Шейлока постепенно. Читатель не испытывает неприязни к жиду, пока речь не заходит о его ненависти к христианам, в частности к купцу Антонио, «человеку хорошему, потому что ему есть чем заплатить», но излишнему гордецу, что «дает взаймы без процентов» и «ругает» ростовщический барыш Шейлока ${ }^{26}$. Еврей избирает тактику насмешек над Антонио, в конце разговора предлагая заключить пари о выплате неустойки (фунта мяса из тела купца) в случае невозможности погашения векселя ${ }^{27}$. Самые драматические страницы те, когда Шейлок проклинает бежавшую с молодым человеком дочь Джессику и весь свой гнев обрушивает на купца, которого одновременно подстерегают все мыслимые и немыслимые несчастья, он теряет все свои суда на море. Шейлок - безжалостен, непреклонен и страшен, он почти лишился рассудка, но движим только одной мыслью - добыть причитающуюся ему неустойку. Поэтому, когда Порция (уже супруга Бассанио), облачившаяся в наряд судьи и вооружившаяся знанием венецианских законов, предлагает Шейлоку деньги, он не слышит голоса разума, а руководствуется только чувством мести ${ }^{28}$. Юрист идет до конца, разоряет еврея и вынуждает его креститься; Шейлок падает духом, но соглашается с решением суда ${ }^{29}$. В конце новеллы он покидает Венецию с укрепившейся затаенной злобой к христианам ${ }^{30}$.

Перевод Гревса - это попытка изложить историю жизни ростовщика-еврея и разобраться в трагической судьбе еврейского народа. Не случайно, что он относил пьесу Шекспира к двойственной драме ${ }^{31}$. Первым ее элементом выступала судьба еврейской нации, которая «рассеяна по свету, но соединена братски между собой, составляя единое целое»; вторым элементом была личная трагедия Шейлока, поставивше-

\footnotetext{
${ }^{26}$ См. там же, с. 4-5.

27 См. там же, с. 6-7.

28 См. там же, с. 29-31.

29 См. там же, с. 31.

30 См. там же, с. 38.

1 См. 0.Б. Вахромеева, Человек с открытым сердчем..., с. 87.
} 
го идею обогащения выше счастья дочери, идеи гуманности и веры своего народа ${ }^{32}$. Перевод Венецианского купца Шекспира Гревсом - это отклик из XIX столетия, попытка разрешить старый историко-культурный конфликт.

\footnotetext{
32 См. И.М. Гревс, Венецианский купец (по Шекспиру)..., с. 11.
} 